\title{
Gasoline Price and Competition: New Evidence from Traffic Pattern
}

\author{
Baohui Liu \\ Texas Tech University
}

Competition is considered as an important factor that influences gasoline prices. In spatial competition, an increased density of competitors has a direct impact on lowering gasoline price. However, prior research omitted an important demand factor: traffic volume. This paper uses a reduced-form approach to test for the relationship between market density and retail gasoline price with and without traffic volume. The omission of traffic volume biases the estimated effect of market density on retail gasoline price and leads to a $61 \%$ overstatement. Furthermore, this paper examines the relationship between market density and price dispersion with and without traffic dispersion.

Keywords: retail gasoline price, price dispersion, market density, and traffic volume

\section{INTRODUCTION}

Law of one price implies that identical goods should have the same price. However, it is interesting that gasoline prices vary so much from station to station. Numerous studies have examined potential factors which could influence gasoline prices. Competition is considered an important issue. Albalate and Perdiguero (2015) find that a lack of competition contributes to higher prices charged by gasoline stations on toll motorways than free motorways.

The existing literature suggests that a competitive market structure enhances price competition in the retail gasoline market and lowers gasoline prices. Furthermore, both market density and closeness of stations matter in competitive retail gasoline markets. For example, Barron, Taylor, and Umbeck (2004) find that an increase in station density consistently decreases both price levels and price dispersion. However, prior research omitted an important demand factor: traffic volume. Before introducing traffic volume into this context, one might think that price decreases as the number of competitors increases. In spatial competition, an increased density of competitors has a direct impact in lowering gasoline price. However, if economies of scale play an important role in retail gasoline markets, stations may charge lower prices when potential consumers increase. Hence, it is possible that gasoline prices are low in hightraffic-volume regions. In addition, retail gasoline stations tend to locate themselves in regions where many vehicles pass by. Netz and Taylor (2002) argued that stations located in close proximity to a major road are less spatially differentiated, which reflects that stations are willing to locate closer to rivals when the distribution of potential consumers becomes more clustered.

This paper presents new estimates on the relationship between gasoline price and market density after controlling for the omitted variable bias in the prior literature. For comparison, this analysis runs two separate regressions: with and without traffic volume. This paper finds that the omission of traffic volume biases the estimated effect of market density on retail gasoline price and leads to a large overstatement. 
For example, the coefficient of number of competitors within $2 \mathrm{~km}$ radius is -0.621 in the regression excluding traffic volume, while it is only -0.24 in the regression including traffic volume.

Furthermore, this paper tests the potential relationship between price dispersion and market density with the introduction of traffic dispersion. Price dispersion and traffic dispersion are measured separately by standard deviation of retail price and traffic volume. Traffic dispersion only has a significant impact on price dispersion when a local market is defined by a $2 \mathrm{~km}$ radius. Specifically, a local market with $50 \%$ higher measure of traffic dispersion would have a $3.43 \%$ higher measure of price dispersion. Within a $2 \mathrm{~km}$ radius, the correlation between market density and price dispersion is not statistically significant.

\section{RETAIL GASOLINE MARKET IN WESTERN AUSTRALIA}

The context of this paper is the retail gasoline market in the state of Western Australia. In Australia, Shell, BP, Caltex, and Mobil are considered as Majors, which are vertically integrated firms with upstream refining and often crude production operations (Wills-Johnson, 2010). Among the Majors, Shell, BP, and Caltex dominate the market in Western Australia (Byrne \& de Roos, 2017). According to the Australian Competition and Consumer Commission, two major supermarket chains, Caltex Woolworths and Coles Express, have become important presences in retail gasoline markets, which have taken a share of roughly 50 percent of the market by volume (as cited in Wills-Johnson, 2010). The remaining stations are largely run by independent retailers, which are usually smaller firms with no upstream operations. Among these retailers, Liberty, Gull, United, 7-Eleven, Peak, and Wesco are important independent players (Wills-Johnson, 2010). This paper categorizes retail gasoline stations into three groups: 1) supermarket chains (Caltex Woolworths and Coles Express); 2) Majors (BP, Caltex, Shell, and Mobil); 3) independent firms (all others).

In Western Australia, FuelWatch scheme is a crucial and unique regulatory regime, which was created to ease motorists' anger over frequent intra-daily price fluctuations. Under the scheme, retail gasoline stations must report fuel prices that they will charge each day by $2 \mathrm{pm}$ of the previous day, the prices are then made public at $6 \mathrm{pm}$ on the FuelWatch website, and actual price changes occur at 6am the following day (Wills-Johnson, 2010). In this way, retail fuel prices are fixed for 24 hours. Terminal gate price (i.e. gasoline and diesel wholesale price) is also monitored and reported on the FuelWatch website.

\section{LITERATURE REVIEW}

This paper relates to previous literature on gasoline price competition that focuses on market density and closeness of stations and introduces a new variable of traffic volume which can be used to control for demand. Clemenz and Gugler (2004) find that a higher station density reduces average prices by using data from the Austrian retail gasoline market. Estimation of the pricing and entry equations as simultaneous equations confirms that causality runs from station density to price. Kvasnička, Staněk, and Krčál (2018) study the effect of station density on prices in the retail gasoline market in the Czech Republic. They find that station density has a negative effect on prices, and the effect decreases with distance and is statistically significant up to six kilometers. Oczkowski, Wong, and Sharma (2018) estimate a reduced form price model to assess the impact that major retailer market concentration, station density, brand effects and other variables may have on prices. Higher degrees of market concentration and lower station density in regional centers are found to impact prices positively. Their findings are robust across various data types, such as individual station level retail price and regional averages.

Kihm, Ritter, and Vance (2016) examine the influence of the Brent crude price on retail gasoline price, focusing on how this influence varies according to the brand and to the degree of competition in the vicinity of station. They confirm a negative relationship between competition density and retail gasoline price by estimating a random effects model. The magnitude of the negative effect diminishes with increases in the Brent crude price. A coherent interpretation rooted in spatial competition is that an increased density of competitors has a direct impact in lowering the price, which, in turn, compels retailers to pass on more of the increase in the Brent crude price. 
The four previous studies focus on market density and retail gasoline price. The next two studies examine the relationship between price dispersion and market density.

Barron et al. (2004) empirically estimate the relationship between seller density, average product price and price dispersion in the retail gasoline industry using four unique gasoline price data sets. Controlling for station-level characteristics, Barron et al. find that an increase in station density consistently decreases both price levels and price dispersion across four geographical areas. This evidence is consistent with variants of the standard models of monopolistic competition, but it is at odds with some of the predictions of widely cited search-theoretic models.

Lewis (2008) measures price dispersion among differentiated retail gasoline sellers and studies the relationship between dispersion and the local competitive environment. Significant price dispersion exists even after controlling for differences in station characteristics, and price differences between sellers change frequently. The extent of price dispersion is related to the density of local competition, but this relationship varies significantly depending on the type of seller and the composition of its competitors.

Neither of these studies consider the effect of traffic volume and traffic dispersion. Building upon them, the main contribution of the present paper is to provide a new explanatory variable (traffic volume) for retail price and price dispersion in retail gasoline markets.

\section{DESCRIPTION OF DATA AND VARIABLE}

Data used in this paper comes from various sources. Firstly, both retail fuel prices and terminal gate prices are collected from the FuelWatch website. As mentioned before, the FuelWatch website is an official website that provides price information at the wholesale and retail levels of the petroleum industry. It has been a reliable data source of retail gasoline price in previous research. However, the FuelWatch data set does not include the information about station characteristics. The station characteristics are looked up by entering station addresses on Google Maps. Station characteristics include brand, carwash or vehicle service, number of pumps, and presence of convenience store. Traffic volume is obtained from the government of Western Australia (Main Roads) through "trafficmap" and it measures average number of vehicles passing by a location from Monday to Sunday. In this analysis, traffic volume is used as a new and reliable variable to control for demand-side effect. Traffic volume is matched to gasoline retailer via station address. In addition, station addresses are converted to geographical coordinates (longitude and latitude) using Google Earth software. With the coordinates, linear distances between gasoline stations are calculated using great circle distance formula. Distance to nearest competitor is the shortest linear distance between a certain station and its competitors. Furthermore, linear distances will be used to derive market density (i.e. number of competitors). In this analysis, number of competitors is defined by three different market radiuses $(2 \mathrm{~km}, 5 \mathrm{~km}$ and $10 \mathrm{~km})$. This paper focuses on retail stations located on highways. As major roads, traffic volume data near highway stations is more reliable and easier to obtain. The omitted-variable bias is more obvious for highway stations. For each highway gasoline station, this paper calculates the distance to its nearest competitor and the number of competitors within its surrounding area. The dataset consists of 86 gasoline stations along highways in Western Australia. Table 1 shows summary statistics of these stations' characteristics. 
TABLE 1

SUMMARY STATISTICS OF STATION CHARACTERISTICS

\begin{tabular}{|l|c|}
\hline Station Characteristics & Number of Stations (\%) \\
\hline Carwash/Vehicle Service & $13 / 86=15 \%$ \\
\hline Convenience Store & $84 / 86=98 \%$ \\
\hline Supermarket Chains & $11 / 86=13 \%$ \\
\hline Majors & $47 / 86=55 \%$ \\
\hline Important Independent Firms & $25 / 86=29 \%$ \\
\hline Other Independent Firms & $3 / 86=3 \%$ \\
\hline Number of pumps $(<=4)$ & $16 / 86=18.6 \%$ \\
\hline Number of pumps $(>4 \&<=8)$ & $53 / 86=61.6 \%$ \\
\hline Number of pumps $(>8 \&<=12)$ & $17 / 86=19.8 \%$ \\
\hline
\end{tabular}

For 86 highway gasoline stations, Table 2 presents summary statistics of their number of competitors with three specifications of market radius. Their competitors include both highway stations and nonhighway stations within surrounding areas. Within a $2 \mathrm{~km}$ radius, 91 percent of highway gasoline stations have at most four competitors. As the market radius increases, the number of competitors rise. Within a $10 \mathrm{~km}$ radius, half of the stations have more than 10 competitors.

TABLE 2

SUMMARY STATISTICS OF NUMBER OF COMPETITORS IN LOCAL MARKET

\begin{tabular}{|l|c|c|c|}
\hline Number of competitors & $2 \mathrm{~km}$ radius & $5 \mathrm{~km}$ radius & $10 \mathrm{~km}$ radius \\
\hline$<=4$ & $78 / 86=91 \%$ & $41 / 86=48 \%$ & $33 / 86=38.372 \%$ \\
\hline$>4 \&<=6$ & $7 / 86=8 \%$ & $3 / 86=3 \%$ & $1 / 86=1.163 \%$ \\
\hline$>6 \&<=10$ & $1 / 86=1 \%$ & $20 / 86=23 \%$ & $8 / 86=9.302 \%$ \\
\hline$>10$ & 0 & $22 / 86=26 \%$ & $44 / 86=51.163 \%$ \\
\hline
\end{tabular}

\section{ESTIMATION METHODOLOGY}

This section explores the impact of traffic volume on price level and price dispersion. It examines how the introduction of traffic volume affects the existing relationship between gasoline price and market density. Brand and station characteristics are controlled for retail gasoline stations. Terminal gate price (i.e. wholesale price) is also included as an important determinant of retail gasoline price.

A reduced-form approach is used to test for the relationship between retail gasoline price and market density with and without traffic volume. The model without traffic volume is described in Equation (1):

$\mathrm{P}_{\mathrm{it}}=\alpha+\beta \mathrm{TGP}_{\mathrm{t}}+\theta \mathrm{COMP}_{\mathrm{i}}+\gamma \mathrm{DST}_{\mathrm{i}}+\lambda \Phi_{\mathrm{i}}+\mu_{\mathrm{it}}$

where $\mathrm{P}_{i t}$ is station i's retail gasoline price at week $t, \mathrm{TGP}_{\mathrm{t}}$ is weekly terminal gate price, $\mathrm{COMP}_{\mathrm{i}}$ represents its number of competitors within surrounding area $\left(2,5\right.$ or $10 \mathrm{~km}$ radius), $\mathrm{DST}_{\mathrm{i}}$ is the abbreviation for distance to the nearest competitor, and $\Phi_{\mathrm{i}}$ is a vector of station characteristics.

For comparison, when traffic volume is included, the modified model is shown in Equation (2):

$\mathrm{P}_{\mathrm{it}}=\alpha+\beta \mathrm{TGP}_{\mathrm{t}}+\delta \mathrm{AADT}_{\mathrm{i}}+\theta \mathrm{COMP}_{\mathrm{i}}+\gamma \mathrm{DST}_{\mathrm{i}}+\lambda \Phi_{\mathrm{i}}+\mu_{\mathrm{it}}$

where $\mathrm{AADT}_{\mathrm{i}}$ stands for traffic volume around station i. Table 3 presents regression results for the reduced-form model with and without traffic volume. All coefficients are denoted in Australian cents per liter. 
Furthermore, this paper measures price dispersion and traffic dispersion in the local market of each highway station and studies the relationship among price dispersion, number of stations and traffic dispersion. Lewis (2008) measures price dispersion as the variance in the error term from a regression of prices on station and week fixed effects. In this analysis, price dispersion and traffic dispersion are separately measured by standard deviation of retail price and traffic volume in a local market. A local market for each highway station is defined as all competing stations that are less than x miles away. In this analysis, each highway station is considered as a center of its local market. Its competitors include both highway stations and non-highway stations within market radius $(2 \mathrm{~km}, 5 \mathrm{~km}$, or $10 \mathrm{~km})$.

Existing theoretical models of price dispersion do not tend to agree in their predictions (Lewis, 2008). For example, the relationship between the number of competing firms and the level of price dispersion differs between search models and spatial competition models. Barron et al. (2004) find that an increase in the density of stations in a spatial model implies less price dispersion with 1.5-mile radius, while search models of Varian (1980) and Carlson and McAfee (1983) find that price dispersion rises with the number of firms. This analysis explores a hypothesized relationship among price dispersion, number of stations, and traffic dispersion. Consistent with Barron et al. (2004) and Lewis (2008), log of price dispersion is regressed on $\log$ of number of stations with the introduction of $\log$ of traffic dispersion. The time invariant model is described in Equation (3):

$\ln \left(\mathrm{PD}_{\mathrm{i}}\right)=\beta_{0}+\beta_{1} \ln \left(\mathrm{TD}_{\mathrm{i}}\right)+\beta_{2} \ln \left(\mathrm{DENSITY}_{\mathrm{i}}\right)+\beta_{3} \mathrm{SAME}_{\mathrm{i}}+\mu_{\mathrm{i}}$

where, for market $\mathrm{i}, \ln \left(\mathrm{PD}_{\mathrm{i}}\right)$ is $\log$ of price dispersion, $\ln \left(\mathrm{TD}_{\mathrm{i}}\right)$ is $\log$ of traffic dispersion, $\ln (\mathrm{DENSITY})$ represents $\log$ of number of stations, $\mathrm{SAME}_{\mathrm{i}}$ represents share of stations with the same brand as center station. Traffic dispersion is excluded from this model. For comparison, Equation (4) estimates the effect of market density on price dispersion in log form:

$\ln \left(\mathrm{PD}_{\mathrm{i}}\right)=\beta_{0}+\beta_{1} \ln \left(\mathrm{DENSITY}_{\mathrm{i}}\right)+\beta_{2} \mathrm{SAME}_{\mathrm{i}}+\mu_{\mathrm{i}}$

\section{EMPIRICAL RESULTS}

The first regression results are presented in Table 3, which compares estimates for the reduced-form model of retail gasoline price with and without traffic volume. This table displays three specifications of market radius when counting number of competitors. Columns 1 and 2 provide estimated coefficients of number of competitors within $2 \mathrm{~km}$ distance and other variables with and without traffic volume. Columns 3 and 4 report the estimation results for number of competitors counted within $5 \mathrm{~km}$ distance. The estimated effects of $10 \mathrm{~km}$ market are compared in the last two columns. All coefficients are denoted in Australian cents per liter. 
TABLE 3

REGRESSION RESULTS WITH AND WITHOUT TRAFFIC VOLUME

\begin{tabular}{|c|c|c|c|c|c|c|}
\hline ULP price & $\begin{array}{l}\mathrm{W} / \mathrm{O} \\
2 \mathrm{~km} \\
\end{array}$ & $\begin{array}{c}\mathrm{W} / \\
2 \mathrm{~km}\end{array}$ & $\begin{array}{l}\mathrm{W} / \mathrm{O} \\
5 \mathrm{~km} \\
\end{array}$ & $\begin{array}{r}\mathrm{W} / \\
5 \mathrm{~km} \\
\end{array}$ & $\begin{array}{l}\mathrm{W} / \mathrm{O} \\
10 \mathrm{~km} \\
\end{array}$ & $\begin{array}{c}\mathrm{W} / \\
10 \mathrm{~km} \\
\end{array}$ \\
\hline COMP & $\begin{array}{c}-0.621 * * * \\
(0.0423)\end{array}$ & $\begin{array}{c}-0.240 * * * \\
(0.0417)\end{array}$ & $\begin{array}{c}-0.248 * * * \\
(0.0108)\end{array}$ & $\begin{array}{c}-0.119 * * * \\
(0.0116)\end{array}$ & $\begin{array}{c}-0.0634^{* * *} \\
(0.00259)\end{array}$ & $\begin{array}{c}-0.0311 * * * \\
(0.00299)\end{array}$ \\
\hline AADT & & $\begin{array}{c}-9.76 \mathrm{e}-05^{* * *} \\
(4.45 \mathrm{e}-06)\end{array}$ & & $\begin{array}{c}-7.50 \mathrm{e}-05^{* * *} \\
(4.89 \mathrm{e}-06)\end{array}$ & & $\begin{array}{c}-6.98 \mathrm{e}-05^{* * *} \\
(5.28 \mathrm{e}-06)\end{array}$ \\
\hline TGP & $\begin{array}{l}0.827 * * * \\
(0.00888)\end{array}$ & $\begin{array}{l}0.828 * * * \\
(0.00866)\end{array}$ & $\begin{array}{l}0.826 * * * \\
(0.00874)\end{array}$ & $\begin{array}{l}0.827 * * * \\
(0.00865)\end{array}$ & $\begin{array}{l}0.826 * * * \\
(0.00872)\end{array}$ & $\begin{array}{l}0.827 * * * \\
(0.00865)\end{array}$ \\
\hline Service & $\begin{array}{c}-1.186^{* * *} \\
(0.154)\end{array}$ & $\begin{array}{c}-0.393 * * \\
(0.162)\end{array}$ & $\begin{array}{c}-0.585^{* * *} \\
(0.155)\end{array}$ & $\begin{array}{l}-0.294^{*} \\
(0.162)\end{array}$ & $\begin{array}{l}-0.235 \\
(0.157)\end{array}$ & $\begin{array}{l}-0.162 \\
(0.161)\end{array}$ \\
\hline Store & $\begin{array}{l}-0.275 \\
(0.324)\end{array}$ & $\begin{array}{l}0.531^{*} \\
(0.322)\end{array}$ & $\begin{array}{c}0.466 \\
(0.314)\end{array}$ & $\begin{array}{c}0.750^{* *} \\
(0.315)\end{array}$ & $\begin{array}{c}1.182 * * * \\
(0.321)\end{array}$ & $\begin{array}{c}1.089 * * * \\
(0.318)\end{array}$ \\
\hline Pump & $\begin{array}{c}-0.468 * * * \\
(0.0250)\end{array}$ & $\begin{array}{c}-0.278 * * * \\
(0.0263)\end{array}$ & $\begin{array}{c}-0.320 * * * \\
(0.0262)\end{array}$ & $\begin{array}{c}-0.253 * * * \\
(0.0267)\end{array}$ & $\begin{array}{c}-0.325 * * * \\
(0.0256)\end{array}$ & $\begin{array}{c}-0.266 * * * \\
(0.0264)\end{array}$ \\
\hline Supermarket & $\begin{array}{c}6.370 * * * \\
(0.312)\end{array}$ & $\begin{array}{c}7.131^{* * *} \\
(0.312)\end{array}$ & $\begin{array}{c}6.680 * * * \\
(0.308)\end{array}$ & $\begin{array}{c}7.088 * * * \\
(0.310)\end{array}$ & $\begin{array}{c}6.915 * * * \\
(0.313)\end{array}$ & $\begin{array}{c}7.157 * * * \\
(0.313)\end{array}$ \\
\hline Majors & $\begin{array}{c}3.434 * * * \\
(0.137)\end{array}$ & $\begin{array}{c}3.808 * * * \\
(0.140)\end{array}$ & $\begin{array}{c}3.411 * * * \\
(0.137)\end{array}$ & $\begin{array}{c}3.690 * * * \\
(0.140)\end{array}$ & $\begin{array}{c}3.339 * * * \\
(0.135)\end{array}$ & $\begin{array}{c}3.624 * * * \\
(0.139)\end{array}$ \\
\hline DST & $\begin{array}{r}0.0336 * * * \\
(0.00227)\end{array}$ & $\begin{array}{c}0.0306 * * * \\
(0.00222)\end{array}$ & $\begin{array}{c}0.0317 * * * \\
(0.00223)\end{array}$ & $\begin{array}{c}0.0307 * * * \\
(0.00222)\end{array}$ & $\begin{array}{r}0.0337 * * * \\
(0.00224)\end{array}$ & $\begin{array}{c}0.0321 * * * \\
(0.00222)\end{array}$ \\
\hline Constant & $\begin{array}{c}29.70 * * * \\
(1.139)\end{array}$ & $\begin{array}{c}28.07 * * * \\
(1.098)\end{array}$ & $\begin{array}{c}28.50 * * * \\
(1.105)\end{array}$ & $\begin{array}{c}27.79 * * * \\
(1.089)\end{array}$ & $\begin{array}{c}27.60 * * * \\
(1.094)\end{array}$ & $\begin{array}{c}27.39 * * * \\
(1.085)\end{array}$ \\
\hline Observations & 8,949 & 8,949 & 8,949 & 8,949 & 8,949 & 8,949 \\
\hline R-squared & 0.542 & 0.564 & 0.558 & 0.566 & 0.560 & 0.566 \\
\hline
\end{tabular}

Robust standard errors in parentheses; ${ }^{* * *} \mathrm{p}<0.01,{ }^{* *} \mathrm{p}<0.05,{ }^{*} \mathrm{p}<0.1$

This finding suggests that traffic volume as a demand factor has a significant negative impact on retail gasoline price. Coefficients on traffic volume vary from -0.0000976 to -0.0000698 in the three specifications of market radius. It is well-known that numerous vehicles travel on major roads (especially highways), so it is reasonable to multiple the coefficient by a number (e.g. 10,000) for a better explanation. Specifically, if the nearby traffic volume increases by 10,000 vehicles, highway gasoline stations will reduce retail prices by 0.976 to 0.698 Australian cents. The negative effect of traffic volume can be explained with economies of scale. Economies of scale makes the long-run supply curve slope downward. With a downward sloping long-run supply curve, an increase in demand could cause a price reduction. Figure 1 illustrates the process. 
FIGURE 1

LONG RUN SUPPLY CURVE

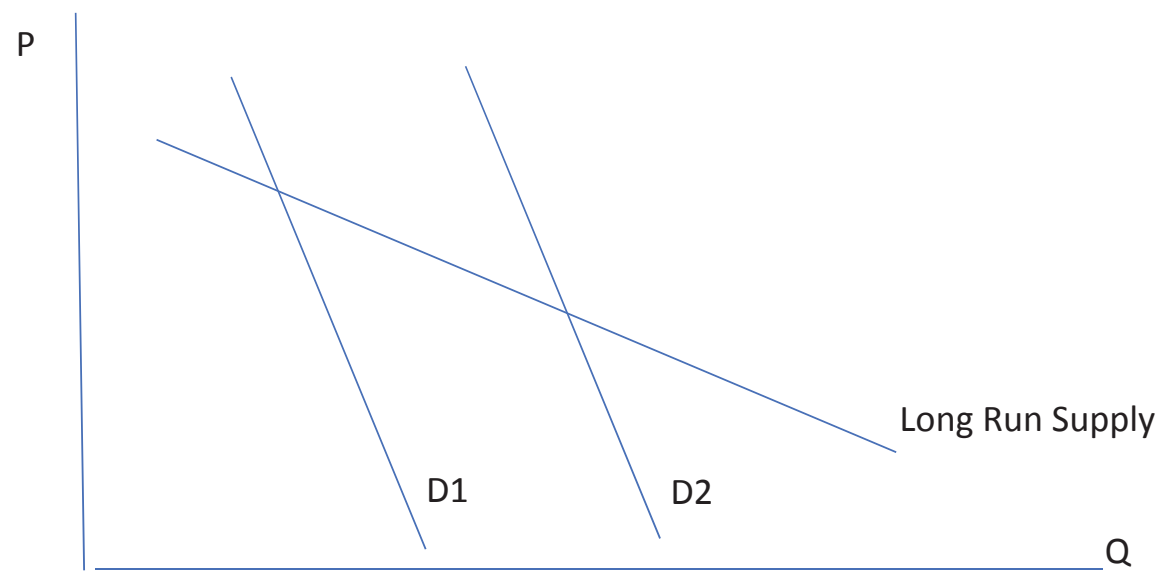

Consistent with existing literature (Barron et al., 2004), stations with a greater number of competitors within any market radius have lower retail prices. However, its impact on retail price varies in magnitude in the models with or without traffic volume. The omission of traffic volume increases coefficients of number of competitors in all three specifications.

For example, with a $2 \mathrm{~km}$ radius, the estimated coefficient of number of competitors in column 1 is 0.621 , while it is only -0.24 in column 2 . Without conditioning of traffic volume, an additional competitor would decrease the retail price of a liter of gasoline by 0.621 Australian cents. When traffic volume is added to the model, an additional competitor would only decrease price by 0.24 Australian cents, which represents a $61 \%$ overstatement. This implies a 0.381 Australian cent overstatement of the effect of an additional competitor on gasoline station prices.

Additionally, the test for equality of coefficients across these two different estimations was rejected (chi2=4.89, $\mathrm{p}=.0269$ ). Similar empirical results are obtained in two other specifications. Therefore, it is concluded that the omission of traffic volume biases the estimated effects of the number of competitors and leads to a large overstatement of this effect as shown in difference in coefficients. 
TABLE 4

RESULTS OF RANDOM EFFECTS MODEL

\begin{tabular}{|c|c|c|c|c|c|c|}
\hline ULP price & $\begin{array}{l}\mathrm{W} / \mathrm{O} \\
2 \mathrm{~km}\end{array}$ & $\begin{array}{c}\mathrm{W} / \\
2 \mathrm{~km}\end{array}$ & $\begin{array}{l}\mathrm{W} / \mathrm{O} \\
5 \mathrm{~km} \\
\end{array}$ & $\begin{array}{c}\mathrm{W} / \\
5 \mathrm{~km}\end{array}$ & $\begin{array}{l}\mathrm{W} / \mathrm{O} \\
10 \mathrm{~km} \\
\end{array}$ & $\begin{array}{c}\mathrm{W} / \\
10 \mathrm{~km}\end{array}$ \\
\hline COMP & $\begin{array}{l}-0.601 * \\
(0.309)\end{array}$ & $\begin{array}{l}-0.228 \\
(0.273)\end{array}$ & $\begin{array}{c}-0.242 * * * \\
(0.0795)\end{array}$ & $\begin{array}{l}-0.115^{*} \\
(0.0609)\end{array}$ & $\begin{array}{c}-0.0626^{* * *} \\
(0.0189)\end{array}$ & $\begin{array}{c}-0.0304 * * \\
(0.0139)\end{array}$ \\
\hline AADT & & $\begin{array}{c}-9.89 \mathrm{e}-05^{* * *} \\
(3.27 \mathrm{e}-05)\end{array}$ & & $\begin{array}{c}-7.72 \mathrm{e}-05^{* * *} \\
(3.08 \mathrm{e}-05)\end{array}$ & & $\begin{array}{c}-7.14 \mathrm{e}-05 * * \\
(3.18 \mathrm{e}-05)\end{array}$ \\
\hline TGP & $\begin{array}{l}0.832 * * * \\
(0.0257)\end{array}$ & $\begin{array}{l}0.832 * * * \\
(0.0257)\end{array}$ & $\begin{array}{l}0.832 * * * \\
(0.0257)\end{array}$ & $\begin{array}{l}0.832 * * * \\
(0.0257)\end{array}$ & $\begin{array}{c}0.832 * * * \\
(0.0257)\end{array}$ & $\begin{array}{l}0.832 * * * \\
(0.0257)\end{array}$ \\
\hline Service & $\begin{array}{l}-1.237 \\
(0.997)\end{array}$ & $\begin{array}{l}-0.431 \\
(1.124)\end{array}$ & $\begin{array}{l}-0.659 \\
(1.009)\end{array}$ & $\begin{array}{l}-0.341 \\
(1.112)\end{array}$ & $\begin{array}{l}-0.315 \\
(1.017)\end{array}$ & $\begin{array}{l}-0.217 \\
(1.089)\end{array}$ \\
\hline Store & $\begin{array}{l}-0.188 \\
(0.966)\end{array}$ & $\begin{array}{c}0.586 \\
(0.857)\end{array}$ & $\begin{array}{c}0.565 \\
(0.706)\end{array}$ & $\begin{array}{c}0.812 \\
(0.709)\end{array}$ & $\begin{array}{l}1.251 \\
(0.949)\end{array}$ & $\begin{array}{l}1.133 \\
(0.846)\end{array}$ \\
\hline Pump & $\begin{array}{c}-0.494 * * * \\
(0.186)\end{array}$ & $\begin{array}{l}-0.297 \\
(0.198)\end{array}$ & $\begin{array}{l}-0.352^{*} \\
(0.196)\end{array}$ & $\begin{array}{l}-0.275 \\
(0.201)\end{array}$ & $\begin{array}{l}-0.352^{*} \\
(0.190)\end{array}$ & $\begin{array}{l}-0.285 \\
(0.198)\end{array}$ \\
\hline Supermarket & $\begin{array}{l}6.354 * * \\
(2.717)\end{array}$ & $\begin{array}{c}7.147 * * * \\
(2.691)\end{array}$ & $\begin{array}{l}6.626^{* * *} \\
(2.652)\end{array}$ & $\begin{array}{c}7.088 * * * \\
(2.660)\end{array}$ & $\begin{array}{l}6.876^{* * *} \\
(2.702)\end{array}$ & $\begin{array}{c}7.160 * * * \\
(2.701)\end{array}$ \\
\hline Majors & $\begin{array}{c}3.459 * * * \\
(0.997)\end{array}$ & $\begin{array}{c}3.870 * * * \\
(1.035)\end{array}$ & $\begin{array}{c}3.407 * * * \\
(1.000)\end{array}$ & $\begin{array}{c}3.739 * * * \\
(1.038)\end{array}$ & $\begin{array}{c}3.370 * * * \\
(0.979)\end{array}$ & $\begin{array}{c}3.687 * * * \\
(1.027)\end{array}$ \\
\hline DST & $\begin{array}{c}0.0333 * * * \\
(0.0116)\end{array}$ & $\begin{array}{c}0.0300 * * * \\
(0.0104)\end{array}$ & $\begin{array}{c}0.0312 * * * \\
(0.0112)\end{array}$ & $\begin{array}{c}0.0301 * * * \\
(0.0108)\end{array}$ & $\begin{array}{c}0.0331 * * * \\
(0.0116)\end{array}$ & $\begin{array}{c}0.0314 * * * \\
(0.0111)\end{array}$ \\
\hline Constant & $\begin{array}{c}29.20 * * * \\
(3.872)\end{array}$ & $\begin{array}{c}27.60 * * * \\
(3.570)\end{array}$ & $\begin{array}{c}27.92 * * * \\
(3.543)\end{array}$ & $\begin{array}{c}27.28 * * * \\
(3.447)\end{array}$ & $\begin{array}{c}27.00 * * * \\
(3.448)\end{array}$ & $\begin{array}{c}26.88 * * * \\
(3.409)\end{array}$ \\
\hline Observations & 8,949 & 8,949 & 8,949 & 8,949 & 8,949 & 8,949 \\
\hline
\end{tabular}

Robust standard errors in parentheses; *** $\mathrm{p}<0.01,{ }^{* *} \mathrm{p}<0.05,{ }^{*} \mathrm{p}<0.1$

To examine the robustness of these findings, additional econometric analysis was conducted. The models described in Equations (1) and (2) were estimated using random effect approach. The results for random effects model are presented in Table 4. Once again, the estimates confirm that traffic volume has a significant impact on retail price and omission of traffic volume biases high effects of the number of competitors.

Table 5 presents regression results of price dispersion with and without traffic dispersion in three specifications. In these specifications, a local market of a highway station is defined by three different market radiuses $(2 \mathrm{~km}, 5 \mathrm{~km}$ and $10 \mathrm{~km})$. 
TABLE 5

REGRESSION RESULTS WITH AND WITHOUT TRAFFIC DISPERSION (TD)

\begin{tabular}{|c|c|c|c|c|c|c|}
\hline $\ln$ (price dispersion) & $\begin{array}{c}\mathrm{W} / \mathrm{O} \mathrm{TD} \\
2 \mathrm{~km} \\
\end{array}$ & $\begin{array}{l}\text { W TD } \\
2 \mathrm{~km} \\
\end{array}$ & $\begin{array}{c}\mathrm{W} / \mathrm{O} \mathrm{TD} \\
5 \mathrm{~km} \\
\end{array}$ & $\begin{array}{l}\text { W TD } \\
5 \mathrm{~km}\end{array}$ & $\begin{array}{c}\text { W/O TD } \\
10 \mathrm{~km} \\
\end{array}$ & $\begin{array}{l}\text { W TD } \\
10 \mathrm{~km} \\
\end{array}$ \\
\hline $\ln$ (DENSITY) & $\begin{array}{c}0.117 \\
(0.104)\end{array}$ & $\begin{array}{r}-0.0455 \\
(0.103)\end{array}$ & $\begin{array}{c}0.163 * * * \\
(0.0428)\end{array}$ & $\begin{array}{l}0.147 * * \\
(0.0636)\end{array}$ & $\begin{array}{c}0.120 * * * \\
(0.0255)\end{array}$ & $\begin{array}{c}0.0983 * * * \\
(0.0351)\end{array}$ \\
\hline $\ln (\mathrm{TD})$ & & $\begin{array}{c}0.0686 * * * \\
(0.0189)\end{array}$ & & $\begin{array}{l}0.00835 \\
(0.0255)\end{array}$ & & $\begin{array}{c}0.0230 \\
(0.0256)\end{array}$ \\
\hline SAME & $\begin{array}{c}0.273 \\
(0.443)\end{array}$ & $\begin{array}{c}0.264 \\
(0.397)\end{array}$ & $\begin{array}{c}0.403 \\
(0.296)\end{array}$ & $\begin{array}{c}0.395 \\
(0.299)\end{array}$ & $\begin{array}{l}0.0561 \\
(0.282)\end{array}$ & $\begin{array}{l}0.0292 \\
(0.284)\end{array}$ \\
\hline Constant & $\begin{array}{c}1.884 * * * \\
(0.126)\end{array}$ & $\begin{array}{c}1.525 * * * \\
(0.150)\end{array}$ & $\begin{array}{l}1.675 * * * \\
(0.0768)\end{array}$ & $\begin{array}{c}1.637 * * * \\
(0.142)\end{array}$ & $\begin{array}{l}1.712 * * * \\
(0.0623)\end{array}$ & $\begin{array}{c}1.578 * * * \\
(0.161)\end{array}$ \\
\hline Observations & 52 & 52 & 61 & 61 & 69 & 69 \\
\hline R-squared & 0.045 & 0.250 & 0.375 & 0.376 & 0.339 & 0.348 \\
\hline
\end{tabular}

Traffic dispersion has a significant impact on price dispersion when a local market of highway station is defined by a $2 \mathrm{~km}$ radius. Specifically, a local market with a $50 \%$ higher measure of traffic dispersion would have a $3.43 \%$ higher measure of price dispersion. Within a $2 \mathrm{~km}$ radius, the correlation between the number of stations and price dispersion is not statistically significant. As market radius increases to $5 \mathrm{~km}$ or $10 \mathrm{~km}$, price dispersion increases significantly with the number of stations in the local market, which is consistent with Chandra and Tappata (2011). Furthermore, the impact of number of stations on price dispersion does not vary too much with and without traffic dispersion in a local market (5km and $10 \mathrm{~km})$. For example, without conditioning of traffic dispersion, a local market with 50\% more competing stations (within $5 \mathrm{~km}$ ) would have an $8.15 \%$ higher measure of price dispersion. When traffic dispersion is added to the model, it would have a $7.35 \%$ higher measure of price dispersion. Same brand share is not a perfect measure because many name brand stations are leased or owned and operated by a local dealer rather than being operated by the parent company (Lewis, 2008). In three specifications, no significant impact exists for share of stations that have the same brand as highway stations.

\section{CONCLUSION}

This paper introduces a new variable (traffic volume) to control for demand. The omission of traffic volume biases upward the estimated effect of market density on retail gasoline price. Without conditioning of traffic volume, an additional competitor (within a $2 \mathrm{~km}$ radius) would decrease the retail price of a liter of gasoline by 0.621 Australian cents. When traffic volume is added to the model, an additional competitor would only decrease price by 0.24 Australian cents, which represents a $61 \%$ overstatement.

Furthermore, traffic volume as a demand factor has a significant negative impact on retail gasoline price. Specifically, if the nearby traffic volume increases by 10,000 vehicles, highway gasoline stations will reduce retail prices by 0.976 to 0.698 Australian cents. However, traffic dispersion only has a significant impact on price dispersion when a local market is defined by a $2 \mathrm{~km}$ radius. That is to say, a local market with $50 \%$ higher measure of traffic dispersion would have a $3.43 \%$ higher measure of price dispersion. 


\section{REFERENCES}

Albalate, D., \& Perdiguero, J. (2015). Entry Regulation Asymmetries and Petrol Competition in a Mixed Motorway Network. Journal of Transport Economics and Policy, 49(4), 603-625.

Barron, J. M., Taylor, B. A., \& Umbeck, J. R. (2004). Number of Sellers, Average Prices, and Price Dispersion. International Journal of Industrial Organization, 22(8-9), 1041-1066.

Byrne, D. P., \& de Roos, N. (2017). Consumer Search in Retail Gasoline Markets. Journal of Industrial Economics, 65(1), 183-193.

Carlson, J. A., \& McAfee, R. P. (1983). Discrete Equilibrium Price Dispersion. pp. 480-493.

Chandra, A., \& Tappata, M. (2011). Consumer Search and Dynamic Price Dispersion: an Application to Gasoline Markets. The RAND Journal of Economics, 42(4), 681-704.

Clemenz, G., \& Gugler, K. (2004). Locational Choice and Price Competition: Some Empirical Results for the Austrian Retail Gasoline Market. Empirical Economics, 31(2), 291-312.

Kihm, A., Ritter, N., \& Vance, C. (2016). Is the German Retail Gasoline Market Competitive? A Spatialtemporal Analysis Using Quantile Regression. Land Economics, 92(4), 718-736.

Kvasnička, M., Staněk, R., \& Krčál, O. (2018). Is the Retail Gasoline Market Local or National? Journal of Industry, Competition and Trade, 18(1), 47-58.

Lewis, M. (2008). Price Dispersion and Competition with Differentiated Sellers. Journal of Industrial Economics, 56(3), 654-678.

Netz, J. S., \& Taylor, B. A. (2002). Maximum or Minimum Differentiation ? Location Patterns of Retail Outlets. The Review of Economics and Statistics, 84(1), 162-175.

Oczkowski, E., Wong, A., \& Sharma, K. (2018). The Impact of Major Fuel Retailers on Regional New South Wales Petrol Prices. Economic Analysis and Policy, 57, 44-59.

Varian, H. R. (1980). A Model of Sales. The American Economic Review, 70, 651-659.

Wills-Johnson, N. (2010). Competition in a Spatial Retail Petroleum Market. (November). 